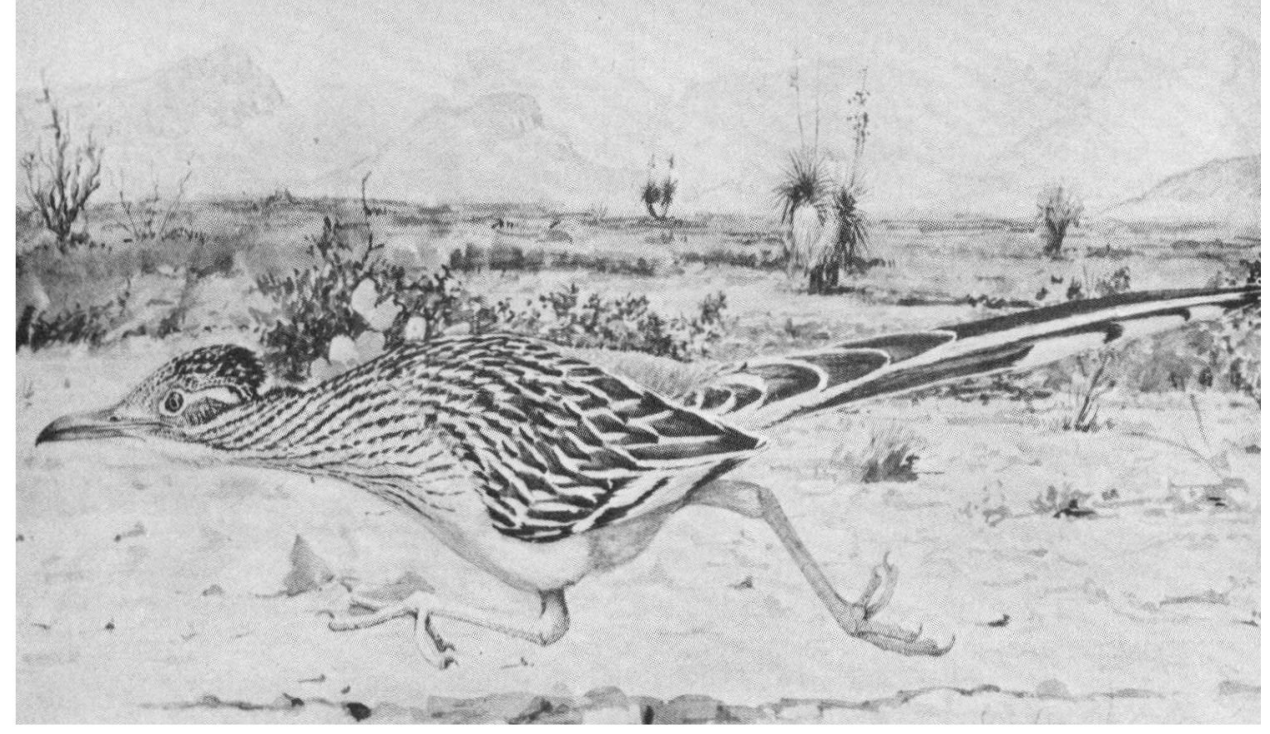

ROADRUNNER, from a painting by Louis Agassiz Fuertes in American Wildlife Painting by Martina R. Norelli, Phaidon, $£ 13.50$, a coffee-table book of beautifully reproduced paintings by Audubon, Catesby, Fuertes, Heade, Thayer and Wilson

whether they be leech-infested rain forests or the arid thorn bush of the dry zone. As she says, 'Ceylon has not only beauty but character-and a soul'. It is in the solitude of the jungle that the feeling of this character and soul will eventually reveal itself as one comes, through time, to appreciate the beliefs and superstitions of these people who live so near to nature.

Iris Darnton describes the buried cities and other ancient and famous ruins, steeped with history, which inspire deep feelings of awe and reverence. But the main object behind this extensive exploration trip was to get to know the birds, many of which are mentioned although none are intimately described. But I envy Iris Darnton her fairy blue bird. In 34 years of extensive birding throughout Ceylon two species avoided me: the Ceylon arrenga and that straggler from South India, the fairy blue bird; she was extremely lucky to see the only one recorded this century.

Today, of course, you cannot expect to find the same jungle and the primitive rest houses described in this account of a journey made in 1947. 'Slum agriculture' having become the order of the day, forests have fallen before the onslaught of the axe and fire, completely changing the environment to the detriment of the endemic fauna and flora.

This is a personal journal of wanderings around the island, describing the places visited, sometimes with rather painful memories of indifferent resthouses and their beds.

The book is liberally illustrated with beautiful black and white photographs, some of which, due to indifferent reproduction, have not been given full justice, and chapter headings are jauntily adorned with the author's pen and ink sketches.

C. E. NORRIS

The Nile, Biology of an Ancient River, edited by Julian Rzoska. Junk, The Hague, 120 Dutch guilders.

This completes a trilogy of recent books which provide a scientific base for the conservation of tropical inland waters, especially those of Africa. The two others, Leonard Beadle's Inland Waters of Tropical Africa, and Rosemary Lowe-McConnell's Fish Communities in Tropical Waters, were noticed in Oryx of February 1976. Julian Rzoska, who is not only editor but also author of a good part of The Nile, was a professor in Poland before the war. After campaigns in Europe he joined Charles Elton in research and control of rodents, and after the war built up a school 
of hydrobiology at the University of Khartoum. Later he was international coordinator of the freshwater section of the IBP and consequently looks at this river from a particularly wide viewpoint.

Of the eighteen contributors, seven are from Egypt and the rest from UK, USA, Hungary and New Zealand. There are early chapters on geology, prehistory and early civilisations before getting deep into biology, where much of the information presented is new, or at least difficult to obtain elsewhere. But treatment of the many subjects is somewhat unequal: thus chapters on the fishes, water characteristics, and swamps are particularly full, while mammals and birds are touched on but briefly. There is the first good account of Lake Nasser, and the environmental influences of the High Dam at Aswan are mentioned at intervals. Rzoska indeed, has done a good job in providing a balanced statement on this controversial subject, further developed in Nature of June 10,1976. He helps to correct the misleading environmental propaganda, which neglects the High Dam's primary objectives while exaggerating its ancillary effects, some of which has unfortunately crept into several ecological texts. Another large controversial project, the Jonglei Canal, which will likewise affect human ecology in a big way, is also touched on.

The book is essentially about conservation in the broadest sense-of environments, of ecosystems, of species, and of water as the life-blood of the Sudan and Egypt. With five other countries providing that water, the Nile is an international river par excellence.

BARTON WORTHINGTON

\section{Rodents in Desert Environments, edited by I. Prakash and P. K. Ghosh. Dr W. Junk, The Hague, DG 180.}

This is a book for the specialist, and a very good one that will undoubtedly retain its importance for many years. Of desert mammals, rodents are unquestionably the most numerous. But although they have attracted a considerable amount of scientific interest and research, this book (vol 28 of Monographiae Biologicae) is the first comprehensive compilation to be made of the available information on their biology in desert environments. The subjects of the 23 chapters, in a book of well over 600 pages, range from a consideration of the desert as a habitat to the nematode parasites of Indian desert rodents. The ecology of rodents in various arid regions is described - including northern Sudan (D. C. D. Happold), Iran (X. Misonne), Afghanistan (J. Gaisler), Rajasthan (I. Prakash), Australia (A. E. Newsome and L. K. Corbett), Argentina (M. A. Mares), and Russia (N. P. Naumov and V. S. Lobachev). The remaining chapters are concerned with water conservation and thermoregulation (K. Schmidt-Nielsen; W. V. Macfarlane; P. K. Ghosh; L. I. Ghobrial and T. A. Nour), reproductive biology (H. D. Smith and C. D. Jorgensen; A. C. Hawbecker), activity (N. R. French), food (M. L. Rosenzweig, Barbara Smigel and A. Kraft), coloration (D. L. Harrison), behaviour patterns (J. F. Eisenberg), ecological adaptations (A. de Vos), and prehistoric faunas (E. Tchernov; Priscilla F. Turnbull). Except for a short chapter in French on the dentation of gerbils ( $F$. Petter), the entire volume is written in English. It concludes with author, genus and species, and subject indexes.

At a time when so many books are being produced as paperbacks, with offset print and unjustified margins, it is a real pleasure to read a book that is well bound, printed on good quality paper, and contains numerous clear illustrations. It is, naturally, expensive. Yet everyone engaged in research on the biology of desert rodents and allied topics will feel deprived if he does not buy himself a copy.

\section{J. L. CLOUDSLEY-THOMPSON}

\section{Correction}

The author of Portraits in the Wild, reviewed in Oryx July 1975, is Cynthia Moss, not Ross. 